\title{
High Court Procedure and the Cost of Patent Actions
}

$\mathrm{A}^{\mathrm{T}}$ the recent meeting in Blackpool of the A British Association, the president of Section G (Engineering), Prof. W. Cramp, gave an address on "The Engineer and the Nation" in which he referred to the difficulties in the way of an inventor who patents his invention and attempts to create a new industry. As an illustration of these difficulties, Prof. Cramp mentioned a patent action within his own experience which cost $£ 30,000$, more than half of which was spent in obtaining a judgment (reversed on appeal) from a judge who, he stated, admitted that "he could hardly understand a word about it". On this state of affairs Prof. Cramp expressed the opinion that "there is no hope for the Patentee in this country under such a clumsy ineffective system; but to change it will be difficult. It will be necessary to break through the resistance of a thoroughly casehardened Bar, and engineers know what that means. I believe that this Association is the only body with the necessary prestige and influence to produce the desired effect. I hope that this Seetion will urge the Council to take steps to bring about a reform that is so long overdue."

Reform of the patent system in Great Britain has been under consideration more than once during recent years, and the net result is that amended Rules of the Supreme Court are at the present moment being put into effect. This position has been reached by two stages. The first stage included the Departmental Committee on the Patents Acts, presided over by Sir Charles Sargant, and a discussion at the centenary meeting of the British Association in London in 1931. After the Departmental Committee had decided that the cost of patent actions was a subject outside its terms of reference, the subject was brought before the British Association at the centenary meeting. At that meeting, papers on "The Development of Invention" were read by nine representative authorities under the chairmanship of Sir James Swinburne, and the related subjects of High Court procedure and the cost of patent actions were carefully considered. There was general agreement that litigation over patents had become so slow and expensive that only the large corporations or companies and wealthy individuals could afford to go to law over patents, and that there was no satisfactory method of obtaining a decision of very numerous disputes arising on patented inventions. Various suggestions for reform were put forward, of which probably the most interesting was one advocating arbitration of the disputes under procedure similar to that adopted under the London Building Acts. The suggestion, briefly, was that the advisers to parties in a patent dispute should call in either a member of the Patent Bar or some other experienced person to act as a third adviser, and that the parties should agree to abide by any award of the three advisers, signed by at least two of them. This suggestion has not apparently been at all widely adopted.

In the second stage, High Court procedure was considered by the Business of Courts Committee, presided over by Lord Hanworth, and recommendations on the subject were made in the Final Report, 1936. The Committee examined suggestions in regard to rearrangements in the constitution of the Court including $(a)$ proposals for the delegation of the hearing of minor patent actions to the Comptroller of Patents or some special officer in his department and $(b)$ proposals for the appointment of a special High Court judge to deal with patent business; and reported against each of these proposals. The Committee further expressed the opinion that the machinery for trial with assessors or with court experts was amply available under existing rules, and that there was not sufficient ground for forcing the machinery upon unwilling parties. In relation to this opinion it should be remembered that Section 31 (1) of the Patents and Designs Acts, 1907-1932, enacts that in an action or proceeding for infringement or revocation of a patent, the court may, if it think fit, and shall on the request of all of the parties to the proceedings, call in the aid of an assessor specially qualified, and try the case wholly or partially with his assistance.

The Business of Courts Committee also considered carefully the possibility of a reform of procedure in the High Court as at present constituted and found an almost universal agreement that it would be desirable, before patent actions come into eourt, that there should be some means adopted of crystallizing the issues, as well of law as of fact. The Committee recommended that the 
rules should be amended so as to enable the judge, (a) to order the parties to embody their scientific evidence in affidavits to be subject to crossexamination and to be exchanged before the hearing in court, and $(b)$ to order the parties to exchange statements (to be signed by counsel), setting out all matters of fact and contentions of law (including contentions on the construction of documents), on which they intend to rely at the trial. These recommendations are now being put into practice by the rules of the Supreme Court (No. 3), 1936 , some of the rules being operative from July 13 this year and the remainder from October 12.

In commenting on the patent case that cost $£ 30,000$ in the English courts, Prof. Cramp stated that "In France, thanks largely to Napoleon's short way with legal privilege the case given above, with an appeal, cost less than one-tenth of the hearing in the English courts. There, to the best of my recollection, the system is as follows. The court sits to determine if there is a case. Having decided in the affirmative three technical experts are appointed, one by each litigant and one by the judge. These three have access to all apparatus, experiments and documents. Each presents an independent report to the judge and on these the issue is decided." It is a fact that, apart from fees paid to some members of the French Bar who are also eminent politicians or senators, the fees of our Patent Bar are higher than those of the French Bar, and it is true that according to the present procedure in France, the evidence of the three experts is not subject to cross-examination in open court. Nevertheless, it would be unwise to infer from Prof. Cramp's statement that opinion in Great Britain is unanimously in favour of adopting the French procedure, and it is significant that, in the Bill at present before the French legislature, provision is made for cross-examination of the experts in open court, and that this system has already been adopted in the United States.

If any inference is to be drawn from this short statement of High Court procedure and the cost of patent actions, it may possibly be that Prof. Cramp's "case-hardened Bar" shows little indication of bending under the stress of the recent changes and not the slightest indication of breaking. The recent changes have established the present position, and it is unlikely that further changes will be adopted until the present position has been tested, unless they are generally acceptable. It is to be hoped, therefore, that, if the Council of the British Association decides to recommend any further change, it will be specified precisely and will be such as to receive the unanimous support of all the parties interested; otherwise it seems highly improbable that the recommendation will "break through the resistance of a thoroughly case-hardened Bar".

\section{Astronomical Telescopes}

Lunettes et télescopes :

theorie, conditions d'emploi, description, reglage. Par Andre Danjon et Andre Couder. Pp. xvi + 715 + 14 plates. (Paris: Editions de la Revue d'Optique theorique et instrumentale, 1935.) 100 francs.

$\mathrm{T}$ HE collaboration of MM. Danjon and Couder has resulted in a notable addition to astronomical literature. The volume under review is the best and most complete book on telescopes that has been written, and it will undoubtedly remain for a long time the standard work on the subject. M. Danjon is the director of the Strasbourg Observatory and a practical astronomer with wide experience; M. Couder, one of the astronomers at the Paris Observatory, is a skilled optician, who made the $81-\mathrm{cm}$. mirror and other optical parts of the reflector at the Forcalquier (Basses-Alpes) station of the Paris Observatory. The excellent photographs that are being obtained with this instrument are a sufficient testimony to the high quality of its optics. The authors were therefore particularly well qualified for their task.

The volume is divided into five parts. The first part deals with the general theory and use of telescopes. The elementary geometrical theory is summarized, and the limitations of this theory caused by the diffraction of light are then considered. This leads naturally to the question of resolving power, which is discussed in relation to the resolving power of the eye in visual observa. tions and to the resolving power of the photographic plate in photographic observations. The observation of point-sources (stars) and of bodies showing a sensible surface (planets, comets, nebulæ, etc.) are separately considered. Of particular value is a chapter on atmospheric agitation, its measurement and its effect on resolving power. 